\title{
Pendampingan Peningkatan Ekonomi Masyarakat Jatirejo, Girimarto Wonogiri Dengan Pengelolaan Bank Sampah
}

\author{
Andri Octaviani ${ }^{1}$, Yosephine Angelina ${ }^{2}$, Tri Widianto ${ }^{3}$, Lukman Ahmad Imron Pahlawi ${ }^{4}$ \\ Progdi Manajemen Informatika ${ }^{1}$, Progdi Manajemen ${ }^{2.4}$, Progdi Akuntansi ${ }^{3}$ \\ STIE AUB Surakarta \\ email : andry.oktavia@stie-aub.ac,id
}

\begin{abstract}
Abstrak
Perkembangan kerusakan lingkungan saat ini banyak terjadi karena disebabkan oleh eksploitasi sumber daya alam dan konsumsi yang berlebihan dikarenakan terjadinya pertumbuhan ekonomi yang cepat. Pemanasan global, penipisan lapizan ozon dan degradasi lingkungan (tanah, udara dan air) merupakan konsekuensi yang harus ditanggung akibat kerusakan lingkungan yang dapat mengancam kesehatan dan jiwa. Maka dari itu perlu kesadaran diri agar dapat melestarikan lingkungan salah satunya dengan menggunakan produk-produk ramah lingkungan. Produk yang dikembangkan adalah produk dari limbah rumah tangga yang bisa di daur ulang menjadi kerajinan atau berang tepat guna.

Tujuan dari pengabdian masyarakat ini adalah untuk memberikan pelatihan pembuatan kerajinan dari limbah rumah tangga dimana memanfaatkan barang bekas yang sudah tidak terpakai. Selain itu, pelatihan ini juga dapat mendorong untuk membuka jiwa kreativitas dan jiwa wirausaha baru di bidang produk ramah lingkungan. Pelatihan akan dilaksanakan di Kecamatan Matesih Kabupaten Karanganyar, peserta pelatihan ditargetkan sebanyak 50 orang dari anggota ibu-ibu PKK di Kecamatan Matesih Kabupaten Karanganyar.
\end{abstract}

Kata kunci: Pengelolaan, Bank Sampah, Limbah Rumah Tangga

\section{PENDAHULUAN}

Pertambahan jumlah penduduk, perubahan pola konsumsi, dan gaya hidup masyarakat telah meningkatkan jumlah timbulan sampah, jenis, dan keberagaman karakteristik sampah. Meningkatnya daya beli masyarakat terhadap jenis bahan pokok dan makanan atau kegiatan penunjang pertumbuhan ekonomi suatu daerah juga memberikan kontribusi yang besar terhadap kuantitas dan kualitas sampah yang dihasilkan, terutama di masa pandemi seperti saat ini. Timbulan sampah meningkat seiring dengan pertumbuhan jumlah penduduk. Di Negara-negara yang sedang berkembang, pertumbuhan penduduk tidak terkendali dan ada kecenderungan bertambahnya wilayah perkotaan. Oleh sebab itu penambahan timbulan sampah menjadi tidak terelakkan (Visvanathan, 2006). Meningkatnya volume timbulan sampah memerlukan pengelolaan. Jika tidak dilakukan pengelolaan sampah yang baik dan benar maka akan menimbulkan dampak negative terhadap lingkungan dan kesehatan manusia. Salah satu metode pengelolaan sampah adalah dengan cara Bank Sampah. Bank sampah adalah suatu tempat untuk memilih dan mengumpulkan sampah yang memiliki nilai ekonomi dan yang dapat didaur ulang dan atau digunakan kembali, serta terdapat kegiatan pelayanan terhadap nasabah bank sampah oleh teller bank (Suwerda, 2012 ). Masalah sampah disebabkan oleh bukan saja karena ketidakmampuan pemerintah dalam penanganan sampah akan tetapi juga disebakan karena peran serta masyarakat yang masih kurang (Munthazah dan Theresia, 2016). Hal inipun terjadi di kecamatan Jatirejo Wonogiri. Jumlah Penduduk yang ada di Kecamatan Jatirejo Wonogiri selalu berubah-ubah setiap bulannya, hal ini dipengaruhi oleh beberapa faktor yaitu adanya Kelahiran, Kematian dan Perpindahan Penduduk. sehingga memiliki kepadatan penduduk yang cukup tinggi dengan demikian jumlah timbulan sampah yang di hasilkan tinggi. Untuk mengurangi jumlah sampah terutama sampah yang dihasilkan dari aktivitas rumah tangga maka perlu dilakukan pengelolaan sampah dengan sistem Bank Sampah.

Permasalahan yang di hadapi masyarakat adalah dengan adanya timbulan sampah yang semakin banyak tentunya akan mempengaruhi kualitas lingkungan $\mathrm{K}$ ecamatan Jatirejo Wonogiri, karena masih kurangnya Sumber Daya Manusia yang akan mengelola bank sampah serta kurangnya pemamahan masyarakat tentang Bank Sampah. Menurut Azwar (2010), sampah adalah sesuatu yang tidak dapat di pergunakan lagi, yang tidak dapat dipakai lagi, yang tidak disenangi dan harus di buang, maka sampah tentu saja harus dikelola dengan sebaik-baiknya, sedemikian rupa, sehingga hal-hal yang negatif bagi 
kehidupan tidak terjadi.

\section{METODE PENGABDIAN}

Berdasarkan permasalahan yang telah diuraikan sebelumnya dan kesepakatan antara tim pengusul dengan mitra, maka solusi yang ditawarkan untuk mengatasi permasalahan yang ada dapat dilakukan dengan metode pendekatan sebagai berikut:

1. Sosialisasi awal, memberikan pengenalan dan pengetahuan dasar mengenai bank sampah kepada masyarakat.

2. Pelatihan Teknis, pertemuan lanjutan dengan memberikan penjelasan detail tentang standarisasi sistem bank sampah, mekanisme kerja bank sampah, keuntungan sistem bank sampah.

3. Pelaksanaan sistem bank sampah, pemeriksanaan kesiapan penyelenggaraan bank sampah

4. Pemantauan dan evaluasi, melakukan pendampingan agar bank sampah yang dikelola berjalan dengan baik

5. Pengembangan, melakukan perluasan bank sampah berdasarkan hasil pemantauan dan evaluasi

\section{HASIL DAN PEMBAHASAN}

1. Kegiatan pelatihan pembukuan sederhana dilaksanakan selama 5 bulan. Pelaksanaan pelatihan tentang soaialisasi serta pendampingan Adapun lokasi pelaksanaan pelatihan bertempat di Balai Desa Jatirejo Wonogiri. Peserta pelatihan terdiri atas Anggota PKK Kecamatan Jatirejo, perangkat dusun, dan masyarakat pelaku UMKM setempat. Peserta pelatihan yang hadir dalam kegiatan pengabdian kepada masyarakat sekitar 50 orang (data terlampir).

2. Pada kesempatan tersebut, ketua dan anggota tim kegiatan pengabdian pada masyarakat ini menjadi narasumbernya. Kegiatan dimulai dengan pemaparan materi mengenai pentingnya kesadaran akan lingkungan terutama tentang sampah. Selanjutnya, pelaksanaan pelatihan pembuatan awal Bank sampah serta pengelolaannya.

3. Narasumber memberikan modul berupa langkah-langkah dalam proses pengelolaan Bank Sampah sederhana.

Tahapan Pelaksanaan Kegiatan

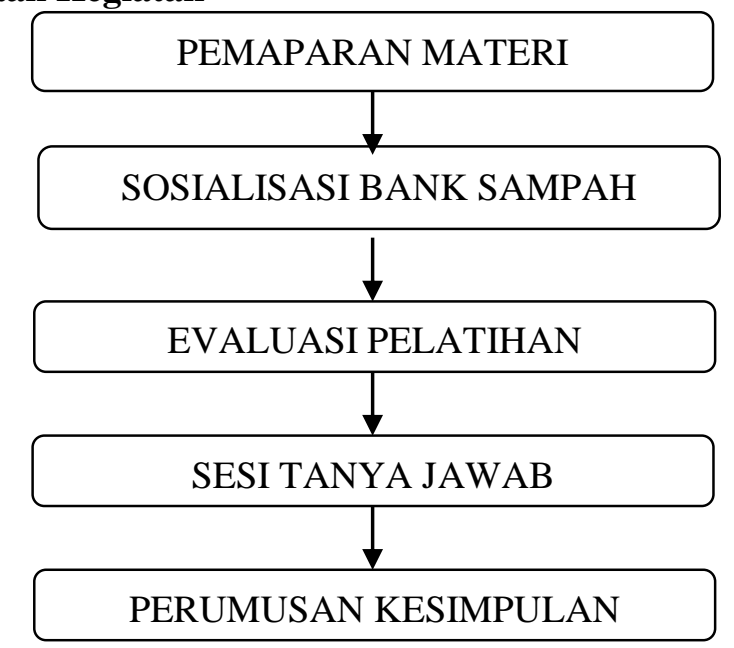


Bagan 1 Tahapan Pelaksanaan

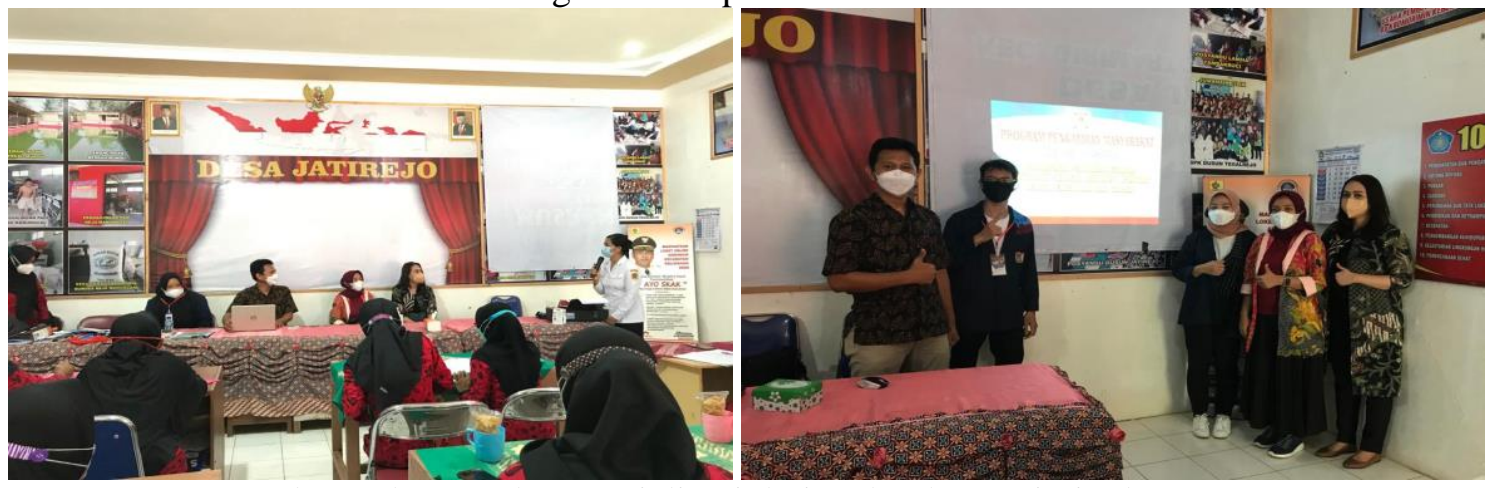

Gambar 1 dan 2 Taham sosialisasi dari Kelurahan Jatirejo dan TIM PKM
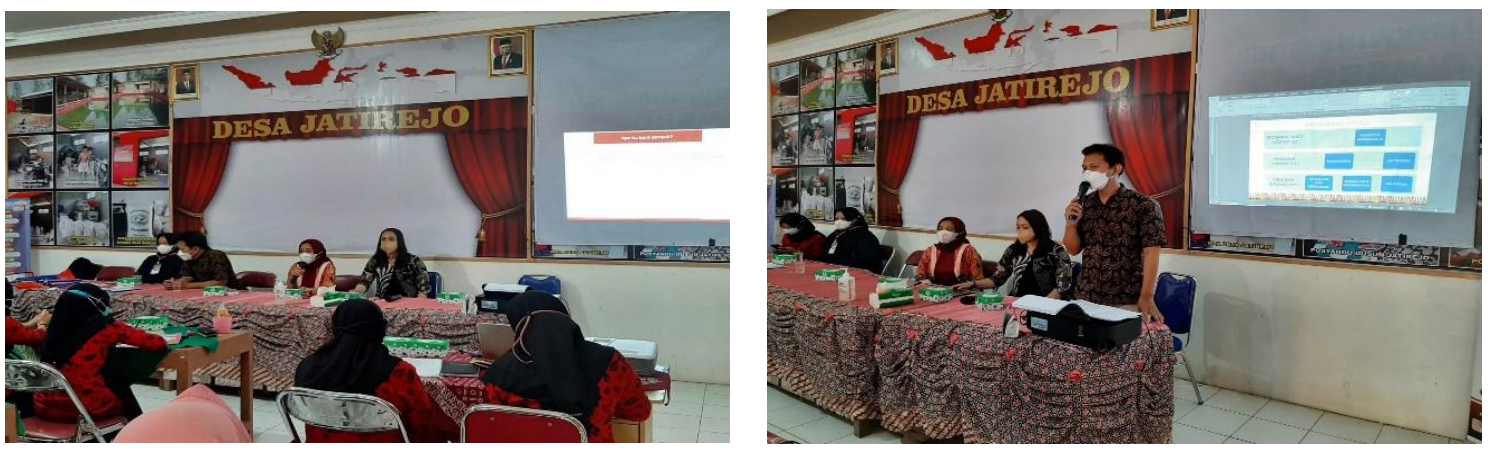

Gambar 3 dan 4 Tahap pelaksanaan Sesi Tanya Jawab Bank Sampah

\section{Pembahasan}

1. Pada kegiatan pelatihan yang telah dilaksanakan menunjukkan antusiasme yang sangat tinggi dari peserta yang merupakan ibu-ibu rumah tangga. Antusiasme tersebut ditunjukkan dengan banyaknya pertanyaan yang diajukan seputar materi pentingnya kesadaran akan lingkungan sekitar. Narasumber berusaha untuk menjawab pertanyaan-pertanyaan tersebut dan memberikan penjelasan yang mendalam mengenai tema yang ditanyakan. Tim pengabdian kepada masyarakat berharap kendala-kendala yang dihadapi dalam pemanfaatan limbah rumah tangga dapat terselesaikan. Tim pengabdian juga berharap, materi yang disampaikan dapat langsung dipraktikkan dalam kondisi nyata oleh ibu-ibu PKK di Kecamatan Matesih Kabupaten Karanganyar.

2. Menurut pengamatan tim pengabdian pada masyarakat bahwa selama pelaksanaan kegiatan pelatihan tersebut nampak bahwa masyarakat di Kecamatan Matesih Kabupaten Karanganyar masih awam dengan pembuatan kerajianan dari limbah rumah tangga. Padahal proses ini penting bagi keberlanjutan usahaya.

\section{Evaluasi}

Keberhasilan pelaksanaan program pengabdian masyarakat ini dilihat dari dua indikator yaitu :

a. Respon posittif dari peserta yang hadir dari awal hingga kegiatan berakhir.

b. Mampu memberikan manfaat bagi peserta dan mudah untuk diterapkan oleh masing-masing masyarakat di Kecamatan Jatirejo Wonogiri.

\section{SIMPULAN}

Berdasarkan hasil dan pembahasan kegiatan pengabdian kepada masyarakat yang telah diuraikan sebelumnya, dapat disimpulkan bahwa :

a. Pemahaman peserta tentang pentingnya kesadaran akan lingkungan hidup semakin tinggi setelah mengikuti pelatihan soaialisasi Bank Sampah di Kecamatan Jatirejo Wonogiri.

b. Kemampuan peserta pelatihan pemahaman tentang sampah dari limbah ruamh tangga menjadikan Bnak Sampah dapat meningkatkan keuangan rumah tangga semakin bersemangat untuk melaksanakan program Bank Sampah. 


\section{SARAN}

Penyelenggaraan program pengabdian kepada masyarakat dengan bentuk penyelenggaraan pelatihan Bank Sampah dari limbah rumah tangga sangat diperlukan dan diharapkan kegiatan seperti dapat dilakukan secara berkesinambungan.

\section{DAFTAR PUSTAKA}

Azwar, Azrul. 2010. Pengantar Ilmu Lingkungan. Jakarta : Mutiara Sumber Widya.

Muntazah, S. Dan I. Theresia, 2016. Pengelolaan Program Bank Sampah Sebagai Upaya Pemberdayaan Masyarakat di Bank Sampah Bintang Mangrove Kelurahan Gunung Anyar Tambak Kecamatan Gunung Anyar Surabaya

http://ejournal.unesa.ac.id/article/17085/14/article.pdf.

Suwerda. 2012. Inovasi Bank Sampah Badegan. Bantul, Jogjakarta. Visvanathan, C, (2005). Asian Regional Research Programme on Sustainable Solid Waste Landfill Management in Asia. Proceeding Sardinia 2005, Tenth International Waste Management and Landfill Sym

Yosephine Angelina, Andri Octaviani, Agus Utomo. 2021. Pendampingan Peningkatan Ekonomi Kreatif Untuk Mengangkat Produk Toga Melalui Digital Marketing Dan Pengemasan Di Desa Sumber Bulu Karanganyar. Jurnal Wasana Nyata Vol 5 No 1. 